\title{
KONSELOR SEBAYA: \\ PEMBERDAYAAN TEMAN SEBAYA DALAM SEKOLAH GUNA MENANGGULANGI PENGARUH NEGATIF LINGKUNGAN
}

\author{
Sarmin \\ Kepala SDN Sumberdiren 01 Kec. Garum Kab. Blitar \\ Email: sarmingarum@gmail.com
}

\begin{tabular}{l}
\hline Tersedia Online di \\
\hline http://www.jurnal.unublitar.ac.id/ \\
index.php/briliant \\
\hline Sejarah Artikel \\
\hline Diterima pada 20 Januari 2017 \\
Disetuji pada 22 Januari 2017 \\
Dipublikasikan pada 1 Februari \\
2017 Hal. 102 - 112 \\
\hline \\
\hline Kata Kunci: \\
konselor sebaya, teman sebaya, \\
sekolah, pengaruh negatif, \\
lingkungan \\
\hline
\end{tabular}

\begin{abstract}
Abstrak: Hubungan sebaya memiliki peranan yang kuat dalam kehidupan remaja. Hubungan sebaya menimbulkan suatu hubungan saling percaya antar teman sebaya. Hubungan ini dapat menimbulkan suatu perilaku dimana remaja lebih percaya terhadap teman sebaya daripada dengan orang tua Sehingga pembentukan dan pelatihan konselor sebaya dapat menjadi suatu pilihan yang tepat dalam upaya membentengi anak atau remaja dari pengaruh negative lingkungan. Hal ini juga yang diterapkan oleh dinas pendidikan kota Surabaya yang mana berhasil menekan dan menanggulangi perilaku menyimpang siswanya. Dalam pemberdayaan ini hendaknya guru tetap memberikan pembinaan, pelatihan dan pendampingan.
\end{abstract}

Hubungan sebaya memiliki peranan yang kuat dalam kehidupan remaja. Fokus dari hubungan sebaya adalah bagaimana seseorang dapat diterima dalam suatu pertemanan dengan teman yang memiliki kesamaan dalam usia, latar belakang ataupun nasib. Hubungan dapat terjadi dengan eratnya. Bahkan hubungan ini dapat memberikan kenyamanan serta kepercayaan antar sebaya.

Kelompok teman sebaya sebagai lingkungan social bagi remaja (siswa) mempunyai peranan yang cukup penting bagi perkembangan kepribadiannya. Peranan itu semakin penting, terutama pada saat terjadinya perubahan dalam struktur masyarakat pada beberapa dekade terakhir ini yaitu (1) perubahan struktur keluarga, dari keluarga besar ke keluarga kecil, (2) kesenjangan antara generasi tua dan generasi muda, (3) ekspansi jaringan komunikasi di antara kawula muda, dan (4) panjangnya masa atau penundaan memasuki masyarakat orang dewasa (Yusuf, 2016:59).

Hubungan sebaya menimbulkan suatu hubungan saling percaya antar teman sebaya. Hubungan ini dapat menimbulkan suatu perilaku dimana remaja lebih percaya terhadap teman sebaya daripada dengan orang tua. Walaupun sejatinya seorang remaja tetap membutuhkan orangtua sebagai pembimbing terutama ketiga menghadapi suatu masalah yang akut. Orang tua tetap sebagai tempat kembali bagi anak atau remaja.

Untuk itu, peran teman sebaya merupakan suatu agen yang strategis dan vital dalam membimbing dan mengarahkan kehidupan remaja. Terlebih 
kepribadian remaja yang memiliki kecenderungan merasa dewasa, ingin menang sendiri dan mencari jati diri. Masa remaja merupakan masa pencarian jati diri

yang mendorongnya mempunyai rasa keingintahuan yang tinggi, ingin tampil menonjol, dan diakui eksistensinya. Namun disisi lain remaja mengalami ketidakstabilan emosi sehingga mudah dipengaruhi teman dan mengutamakan solidaritas kelompok (Pratiwi, 2011:347).

Sehingga pembentukan dan pelatihan konselor sebaya dapat menjadi suatu pilihan yang tepat dalam upaya membentengi anak atau remaja dari pengaruh negative lingkungan. Serta dampak negative pergaulan yang semakin bebas seiring pesatnya perkembangan teknologi.

\section{PEMBAHASAN}

\section{Teman Sebaya}

Teman sebaya merupakan teman sepermaian yang ada disekitar individu yang memiliki usia relatif sama. Selain ditinjau dari kesamaan usia, sebaya juga bisa ditinjau dari kesamaan kedewasaan. Teman sebaya adalah orang dengan tingkat umur dan kedewasaan yang kira - kira sama (Santrock, 2007:205). Kelompok teman sebaya adalah sekelompok teman yang mempunyai ikatan emosional yang kuat dan siswa dapat berinteraksi, bergaul, bertukar pikiran, dan pengalaman dalam memberikan perubahan dan pengembangan dalam kehidupan sosial dan pribadinya (Usman, 2013:58).

Teman sebaya tidak terbatas pada gender tertentu. Bahkan seringkali ditemukan grup sebaya yang anggotanya lintas gender. Dalam satu grup yang cukup besar terdiri dari anak laki-laki dan perempuan dengan rentang usia dan kedewasaan yang relatif sama. Hubungan demikian sudah dilakukan sejak seseorang lahir dan akan terus berlanjut. Melalui hubungan - hubungan dengan teman sebaya orang akan melakukan berbagai hal yang menjadi keyakinan bersama. Lebih lanjut dikatakan Hidayati (2016:32) Peran teman sebaya sangat berpengaruh pada perilaku untuk menunjukkan identitas dirinya, agar dapat diterima dan diakui oleh kelompok.

Sebaya memiliki kecenderungan untuk membuat grup-grup sebaya berdasarkan kesamaan - kesamaan tertentu. Hal ini dilakukan sebagai upaya anak dalam kelompok tersebut untuk mempelajari lingkungan disekitarnya, mendapatkan informasi tertentu serta mengukur kemampuannya. Seperti dikatakan Santrock (2007:205) bahwa salah satu fungsi terpenting dalam sebaya adalah memberikan sumber informasi dan perbandingan tentang dunia luar keluarga. Teman sebaya merupakan tempat bagi remaja untuk memperoleh motivasi dan melepaskan ketergantungan dari orangtua dan orang dewasa lain (Ardi, 2012:2).

Anak -anak menerima umpan balik tentang kemampuan mereka dari grup sebaya mereka. Dari umpan balik tersebut kemudian anak akan mengevaluasi apa - apa saja yang telah mereka miliki. Yang mana hubungan timbal balik tersebut akan sulit mereka temukan dalam lingkungan keluarga. Dikarenakan perbedaan usia antar individu dalam satu saudara yang biasanya lebih tua atau lebih muda.

103 BRILLIANT: Jurnal Riset dan Konseptual Volume 2 Nomor 1, Februari 2017 
Timbal balik yang terjadi akan memunculkan suatu interaksi sosial antar sebaya. Interaksi sosial yang baik akan mengembangkan sosioemosional yang normal, terutama ketika telah mencapai usia remaja. Seperti dikatakan Strantrock (2007:205) bahwa hubungan sebaya yang baik diperlukan untuk perkembangan sosioemosional yang normal. Anak anak yang menarik diri, yang ditolak oleh sebaya atau menjadi korban dan merasa kesepian, memiliki risiko untuk mengalami depresi. Ketika sudah mencapai depresi maka akan muncul perilaku agresif yang mengarah kepada hal negatif.

Hubungan sosioemosional yang normal akan membawa anak pada keterampilan dan timbal balik yang positif. Melalui hubungan sosioemosional yang memunculkan suatu interaksi sebaya anak belajar bagaimana cara berinteraksi yang simetrtis dan timbal balik. Hal ini menurut Santrock (2007:205) dikarenakan orang tua memiliki pengetahuan atau otoritas yang lebih besar daripada anak, interaksi orang tua-anak seringkali mengajar anak bagimana menyesuaikan diri dengan peraturan dan regulasi. Sebaliknya hubungan sebaya lebih cnderung terjadi secara setara.

Dengan sebaya, individu belajar merumuskan dan mengungkapkan pendapat, menghargai sudut pandang sebaya, merundingkan solusi atas perselisihan secara kooperatif, dan mengubah perilaku yang diterima oleh sebaya. Selain itu mereka juga akan menjadi pengamat yang tajam terhdap minat dan prespektif sebaya dalam mengintgrasikan diri secara utuh dalam aktivitas seabaya. Sullivian (dalam Santrock, 2007:205) menambahkan bahwa melalui sebaya remaja belajar menjadi pasangan-pasangan yang terampil dan sensitif dalam hubungan dekat dengan membentuk persahabatan yang erat dengan sebaya terpilih.

Selain itu, Piaget dan Kohlberg (dalam Santrock, 2007:205) juga mengemukakan fungsi lain dari grup sebaya. Menurut Piaget dan Kohlberg, hubungan teman sebaya yang diwarnai memberi dan menerima, anak-anak akan mengembangkan pemahaman sosial dan logika moral mereka. Anak-anak menggali prinsip keadilan dan kebaikan dengan menghadapi perselisihan dengan sebaya.

Hubungan sebaya akan mengarah pada negatif atau positif (Santrock, 2007:206). Adakalanya kelompok sebaya yang beranggotakan individu-individu baik akan menularkan perilaku positif pada sebayanya. Adakalanya kelompok sebaya yang berangotakan individu yang kurang baik akan menularkan perilaku negatif pada sebayanya. Sehubungan dengan hal tersebut dikatakan bahwa pengaruh yang diberikan grup sebaya bergantung pada latar dan konteks spesifiknya. Hal ini didukung oleh Brwon (dalam Sntrock, 2007:206) yang mengatakan bahwa sebuah grup sebaya remaja merujuk kepada orang-orang lingkungan tetangga, orang-orang rujukan, tim olahraga, kelompok sahabat, dan teman.

Dengan demikian dapat ditarik suatu kesimpulan bahwa fungsi grup sebaya dapat digolong menjadi tiga, yaitu (1) Sebagai sumber informasi mengenai dunia di luar keluarga. (2) Sumber kognitif, untuk pemecahan masalah dan perolehan pengetahuan. (3) Sumber emosional, untuk mengungkapkan ekspresi 
dan identitas diri. Yang ketiga fungsi tersebut akan memberikan dampak yang lauar biasa bagi perkembangan anak.

\section{Perkembangan Hubungan Sebaya}

Pada usia balita, anak-anak lebih banyak menghabiskan waktunya untuk bermain dengan sebayanya yang berjenis kelamin sama dibandingkan dengan lawan jenis. Preferensi tersebut akan terus meningkat kualitasnya pada awal masa kanak-kanak. Walaupun interaksi agresif dan permainan yang kasar meningkat, proporsi pertukaran yang agresif, dibandingkan dengan pertukaran yang ramah, menurun (Santrock, 2007:206). Lebih lanjut, dikatakan Rubin (dalam Santrock, 2007:206) banyak anak - anak prasekolah menghabiskan waktu yang cukup lama dalam interaksi sebaya hanya dengan mengobrol dengan teman bermain tentang menegosiasikan peran dan aturan dalam permainan, berdebat, dan setuju.

Ketika memasuki masa sekolah dasar, timbal balik menjadi sangat penting dalam hubungan sebaya. Anak-anak bermain, berkelompok, dan membina persahabatan. Hingga kira-kira usia 12 tahun, prefernsi mereka akan kelompok berjenis kelamin sama meningkat. Jumlah waktu yang dihabiskan anak - anak dalam interaksi sebaya meningkat dari kira-kira $10 \%$ pada usia 2 tahun, $20 \%$ pada usia 4 tahun, dan lebih dari $40 \%$ pada usia 7 dan 11 tahun. Hari sekolah biasanya mencakup 299 interaksi dengan sebaya (Desmita, 2015: 184-185).

Selain hal tersebut, perubahan yang mencolok pada akhir masa kanak kanak adalah peningkatan jumlah anggota dalam grup sebaya serta interaksi mereka yang lebih sedikit diawasi orang dewasa (Rubid, dkk, dalam Santrrock, 2007: 206).

Interaksi yang banyak pada masa sekolah dasar mengambil bentuk yang bervariasi-kooperatif dan kompetitif, bising dan hening, bergembira dan memalukan. Dalam masa ini pengaruh jenis kelamin (gender) semakin berpengaruh. Gender tidak hanya mempengaruhi komposisi kelompok anak, tetapi juga ukuran dan inetraksi di dalamnya (Macoby, dalam Santrock, 2007:207). Anak perempuan cenderung untuk membentuk kelompok yang kecil dan lebih menyenangi pada aktivitas - aktivitas yang tidak berbahaya dan banyak terlibat pada percakapan-percakapan kolaboratif. Sedangkan anak laki - laki cenderung untuk membentuk kelompok besar dan lebih menyenangi kegiatan - kegiatan ekstrem, kompetisi, pertunjukan ego, dan mencari dominasi.

Orang tua sebagai bagian dari keluarga memiliki peranan penting dalam penentuan kepribadian anak. Otomatis dalam hal ini juga mempengaruhi perilaku anak mereka. Bahkan perilaku hubungan sebaya anak juga dikaitkan dengan perilaku orang tua dalam mendidik dan mengatur anaknya. Orang tua mungkin mempengaruhi hungungan sebaya anak melalui banyak cara, baik langsung maupaun tidak langsung. Karena suatu hal, mereka mungkin saja melatih anak mereka cara berhubungan dengan sebaya (Ladd \& Petit, dalam Santrock, 2007:207). Lebih lanjut hasil inverstigasi Rubin \& Sloman (dalam Santrock, 2007:207) orang tua menunjukkan bahwa mereka merekomendasikan strategi tertentu kepada anak mereka terkait dengan hubungan sebaya.

Orang tua juga mempengaruhi hubungan sebaya anak mereka melalui cara mereka mengatur kehidupan anak mereka dan kesempatan mereka untuk

105 BRILLIANT: Jurnal Riset dan Konseptual Volume 2 Nomor 1, Februari 2017 
berinteraksi dengan teman sebaya. Hasil penelitian oleh Ladd \& Hart (dalam Santrock, 2007: 207) menunjukkan bahwa orang tua yang sering memulai kontak sebaya untuk anak mereka yang berusia prasekolah memiliki anak-anak yang lebih diterimaoleh sebaya mereka dan memiliki tingkat perilaku prososial yang lebih tinggi. Lebih lanjut pilihan lingkungan yang diberikan oleh orang tua akan menentukan pilihan lingkungan sebaya yang dipilih anak.

Hubungan orang tua dan anak memiliki fungsi emosional untuk menjelajahi dan menikmati hubungan sebaya. Hubungan orang tua - anak tersebut juga memperlihatkan perilaku anak terhadap sebaya. Beberapa anak yang ahli penggertak dengan beberapa anak yang menjadi korban memiliki sejarah hubungan orang tua -anak yang berbeda. Orang tua anak ahli penggertak sering menolak mereka, bersifat otoritarian, dan bersifat permisif terhadap perilaku agresif anak mereka, dan keluarga anak pengertak diatndai oleh percekcokkan. Sebaliknya orangtua korban adalah pengkhawatir dan terlalu protektif, melakukan pengawasan khusus untuk menghindarkan anak mereka dari agresi (gertakan) (Santrock, 2007:208). Dalam perkembangannya, anak yang mampu beradaptasi dengan dengan baik adalah anak yang tidak terlibat dalam upaya penggertakan dan sebagai korban gertak. Orang tua anak tersebut tidak menghukum perilaku agresif dan keterlibatan responsif mereka dengan putra mereka menghasilkan perkembangan sifat asertif.

Walaupun demikian, anak tetap belajar tentang cara- cara lain selain yang diajarkan orang tua dalam berhubungan dengan sebaya. Dunia anak dan orang tua adalah dua dunia yang berbeda. Namun keduanya saling terkoordinasi secara emosional dan struktur. Ketika anak bermain maka inilah hubungan anak dengan sebayanya, ketika stres anak akan kembali kepada orang tua, inilah hubungan orang tua dan anak. Dalam hubungan orangtua- anak, anak belajar untuk bagaimana berhubungan dengn figur pemegang otoritas. Dalam hubungan sebaya anak lebih berinteraksi pada posisi yang jauh lebih setara dan belajar cara berhubungan yang dipengaruhi oleh timbal balik.

\section{Status Sebaya}

Status sebaya diukur dengan pengukuran sosiometrik. Penerapannya yaitu dengan meminta anak mengujur seberapa jauh mereka menyukai atau tidak menyukai masing- masing teman sekelas mereka. Dari pengukuran tersebut didiapt lima status sebaya sebagai berikut, (1) Anak-anak populer, (2) anak-anak rata-rata, (3) anak-anak yang diabaikan, (4) anak-anak yang ditolak, (5) anak-anak kotroversial.

Anak - anak populer memiliki sejumlah kemampuan sosial yang membantu mereka disukai (Santrock, 2007:211). Anak-anak yang ditolak oleh sebaya mereka cenderung kurang terlibat dalam partisipasi di kelas, lebih cenderung mengutarakan keinginan untuk menghindari sekolah, dan cenderung lebih sering merasa kesepian dibanding anak-anak yang diterima oleh sebaya mereka (Buhs\&Ladd, dalam Santrock, 2007:211).

John Coie (dalam Santrock, 2007:211), memberikan tiga alasan mengapa anak yang agresif memiliki masalah dalam hubungan sosial. Adapaun alasan tersebut adalah sebagai berikut, (1) Anak anak agresif yang ditolak tersebut lebih 
implisif dan memiliki masalah dalam mempertahankan perhatian. Hasilnya, mereka lebih cenderung mengacau dalam kegiatan di kelas dan dalam permainan kelompok. (2) Anak-anak agresif yang ditolak tersebut lebih reaktif secara emosional. Kemaraan mereka lebih mudah tersulut dan mereka mungkin lebih sulit menenangkan diri ketika marah. Karena hal ini, mereka lebih cenderung marah pada sebaya dan menyerang secara verbal dan fisik. (3) Anak anakyang ditolak memiliki kemampauan sosial yang lebih sedikit dalam berteman dan mempertahankan hubungan yang positif dengan sebaya.

\section{Konselor Sebaya}

Kemudian didasari pentingnya dan vitalnya peran teman sebaya dalam perkembangan anak maka muncullah suatu gagasan tentang konselor sebaya. Konselor sebaya adalah pendidik sebaya (tutor sebaya) yang secara fungsional punya komitmen dan motivasi yang tinggi untuk memberikan konseling bagi kelompok remaja/mahasiswa sebayanya, telah mengikuti pelatihan/orientasi konseling (BKKBN, 2012:13).

Gagasan tersebut dianggap penting mengingat fungsi-fungsi dari tema sebaya. Juga untuk membantu anak untuk memecahkan masalahnya serta menghindari pengaruh negatif yang ditumbulkan oleh pertemanan dengan teman sebaya. Keeratan, keterbukaan dan perasaan senasib yang muncul diantara sesama remaja dapat menjadi peluang bagi upaya fasilitasi perkembangan remaja. Pada sisi lain, beberapa karakteristik psikologis remaja (antara lain emosional, labil) juga merupakan tantangan bagi efektifitas layanan terhadap mereka (Suwarjo, 2008:1). Konseling sebaya memungkinkan siswa memiliki keterampilan guna mengimplementasikan pengalaman kemandirian dan kemampuan mengontrol diri secara bermakna bagi remaja. Secara khusus, konseling teman sebaya tidak memfokuskan pada evaluasi isi, namun lebih memfokuskan pada proses berfikir, poses perasaan, dan proses pengambilan keputusan (Wahid, 2013:7).

Dibutuhkan sebuah strategi pengelolaan bimbingan konseling yang baru untuk membantu siswa dalam memecahkan permasalahan pribadinya. Salah satu strategi yang dapat digunakan adalah dengan membentuk kelompok konselor sebaya (Shohib, 2016:35). Hal ini dapat dipahami karena periode remaja merupakan periode yang sangat dekat dengan peer group, membutuhkan pengakuan dari kelompok atau teman sebaya dan membutuhkan identitas baru yang bisa meningkatkan harga dirinya (Hurlock, 2002). Hal ini juga yang mungkin mendasari suatu perilaku dimana anak (remaja) lebih memilih untuk menyampaikan curahan hatinya kepada teman sebaya dari pada kepada orang tua. Diman teman sebaya memiliki persamaan dan bahasa khas sebaya yang lebih diterima anak.

Dalam layanan bimbingan dan konseling terhadap berbagai fungsi antara lain (a) Pemahaman, yaitu fungsi untuk membantu peserta didik memahami diri dan lingkungannya, (b) Pencegahan, yaitu fungsi untuk membantu peserta didik mampu mencegah atau menghindarkan diri dari berbagai permasalahan yang dapat menghambat perkembangan dirinya, (c) Pengentasan, yaitu fungsi untuk membantu peserta didik mengatasi masalah yang dialaminya, (d) Pemeliharaan dan pengembangan, yaitu fungsi untuk membantu peserta didik memelihara dan 
menumbuh-kembangkan berbagai potensi dan kondisi positif yang dimilikinya (Shohib, 2016:35). Selain dalam hal pendidikan dalam kelas, biasanya konselor sebaya juga melayani konseling tentang kasus kehidupan-khas remaja seperti persahabatan, perilaku, dan percintaan. Namun, konselor sebaya pada hakikatnya adalah anak pada usia yang masih setara dengan klien yang masih kurang dari segi pengalaman. Oleh karena itu, tetap diperlukan pendampingan oleh orang dewasa.

Gagasan tentang konselor sebaya telah diterapkan di berbagai instansi seperti sekolah, perguruan tinggi, dan Pusat Informasi dan Konseling Remaja/Mahasiswa (PIK R/M) yang berada dibawah naungan Badan Kependudukan dan Keluarga Berencana Nasional (BKKBN). Efektivitas dari gagasan tersebut telah dapat diakui. Dibuktikan oleh hasil penelitian Maryatun (2011:739) tentang proses penerapan konselor sebaya melalui PIK R/M. Hasil penelitian tersebut menyatakan bahwa dari 20 kelompok PIK R/M 16 kelompok telah memberdayakan konselor sebaya dengan baik dampaknya terjadi perkembangan dan perubahan perilaku siswa yang positif dari sebelumnya memiliki kecenderungan berperilaku negatif.

Sampai saat ini pemberdayaan konselor sebaya terus digalakkan serta dikembangkan. Konsep ini ternyata efektif dan efisien dalam memcahkan permasalahan sebaya. Bahkan dewasa ini jaringan kelompok PIK R/M di Indonesia semakin luas dan terus berkembang. Selain itu, mulai banyak pemerintah daerah yang secara khusus memberikan perhatian pada pemberdayaan konselor sebaya untuk mengembangkan kualitas pendidikan dan pembelajaran serta karakter siswa.

\section{Konselor Sebaya: Best Practice}

Surabaya (Antara Jatim) - Dinas Pendidikan (Disdik) Kota Surabaya menerapkan Program Konselor Sebaya guna melindungi anak-anak dari pengaruh negatif akibat pergaulan salah di lingkungannya. Kepala Dinas Pendidikan Kota Surabaya, M. Ikhsan, di Surabaya, Minggu, mengatakan untuk mengantisipasi tindakan negatif yang dilakukan anak-anak, tidak hanya cukup hanya mengandalkan pengawasan para guru di lingkungan sekolah. "Namun dengan adanya program Konselor Sebaya tentunya akan membantu pengawasan di kalangan para siswa. Program ini dijalankan para pelajar yang mempunyai kepedulian terhadap masalah yang dihadapi teman-temannya," katanya.

Menurut dia, biasanya jika ada masalah, siswa takut menyampaikan ke orang tua atau guru, melainkan lebih banyak curhatnya ke media sosial atau teman. Ikhsan menerangkan, dalam pelaksanaan program itu, tiap kelas dipilih 2 orang siswa yang menjadi konselor atau teman curhat. Biasanya, mereka yang dipilih adalah pengurus kelas atau teman-teman yang menonjol di kelas. "Mereka yang menjadi konselor diajari modul-modul yang yang berkaitan dengan cara berkomunikasi dengan siswa lainnya," katanya. Ia mengatakan, curhat para siswa yang disampaikan ke konselor sebaya akan didiskusikan ke guru Bimbingan dan Konseling (BK) agar masalah yang dihadapi bisa segera diatasi.

Program Konselor Sebaya yang digagas Dinas Pendidikan Surabaya telah berjalan selama 3 tahun. Dan saat ini, menurut Ikhsan, program tersebut

108 BRILLIANT: Jurnal Riset dan Konseptual Volume 2 Nomor 1, Februari 2017 
berkembang menjadi ekstra kulikuler siswa. "Sudah hampir setahun ini, Program Konselor Sebaya menjadi ekskul siswa di sekolah," katanya. Ikhsan mengakui untuk mengantisipasi tindakan negatif yang dilakukan anak-anak, tidak cukup hanya mengandalkan pengawasan di lingkungan sekolah karena selepas sekolah juga membutuhkan pantauan yang ekstra dari orang tua maupun masyarakat.

Ia mengatakan untuk menciptakan kenyamanan di lingkungan, Wali Kota Surabaya telah menginisiasi program "Kampunge Arek Suroboyo". Program tersebut meliputi, Program Kampung Kesehatan, kampung Pendidikan dan Kampung Aman."Warga diminta komitmen untuk menciptakan rasa aman lingkungan sekitarnya," katanya. Ikhsan mencontohkan, dalam penerapan Kampung Pendidikan, pada jam belajar malam hari, anak-anak diharapkan tidak ke luar rumah. Pada malam hari anak-anak diharapkan belajar dengan didampingi orang tua. "Efeknya orang tua bisa bersama anak, sekaligus bisa menjaga anaknya," katanya.

Melalui Program Kampunge Arek Suroboyo, para orang tua bisa memantau anak-anak di lingkungan masyarakat. Apabila ada anak-anak yang bermain di saat jam pelajaran beralangsung, mereka bisa langsung menegurnya. "Jadi bukan lagi linmas atau Satpol PP yang bertindak," jelasnya. Program Kampunge Arek Suroboyo ini menurutnya sudah berjalan satu tahun ini. Melalui program ini, diharapkan para orang tua lebih peduli terhadap lingkungan sekitarnya.

\section{Analisis Teoritis}

Dari praktik tersebut diketahui bahwa pemerintah kota Surabaya dan memberdayakan Konselor sebaya dalam sekolah guna menanggulangi perilaku menyimpang remaja. Pada berita tersebut bagaimana keberhasilan kota Surabaya yang telah menerapkan program konselor sebaya dalam pendidikan. Kota Surabaya melalui dinas pendidikan menerapkan program konselor sebaya secara khusus dalam proses belajar mengajar di kelas maupun lingkungan sekolah. Hal ini menunjukkan bahwa dinas pendidikan memiliki perhatian khusus dan sangat antisipatif dalam menghadapi dampak-dampak negatif yang bisa timbulkan dari pergaulan yang salah. Apalagi Surabaya sebagai kota besar tentu menjadi kota dengan segala permasalahan yang kompleks termasuk perilaku menyimpang anak atau remaja.

Maka pemerintah Surabaya telah menerapkan program konselor sebaya. Seperti diketahui konselor sebaya adalah pendidik sebaya (tutor sebaya) yang secara fungsional punya komitmen dan motivasi yang tinggi untuk memberikan konseling bagi kelompok remaja/mahasiswa sebayanya, telah mengikuti pelatihan/orientasi konseling (BKKBN, 2012:13). Konselor sebaya adalah teman sebaya yang telah dilatih secara khusus untuk dapat memberikan konseling kepada sebayanya. Mereka selain memiliki kompetensi juga didasari sifat peduli terhadap sebayanya yang sedang memiliki permasalahan dan ingin ikut untuk membantu memcahkan permasalahannya.

Seperti dikatakan oleh M. Ikhsan selaku Kepala dinas pendidikan pendidikan kota Surabaya bahwa dengan adanya program Konselor Sebaya 
tentunya akan membantu pengawasan di kalangan para siswa. Program ini dijalankan para pelajar yang mempunyai kepedulian terhadap masalah yang dihadapi teman-temannya. Hal tersebut membuktikan bagaimana konselor sebaya menjadi alternatif pilihan yang relevan dalam menanggulangi kenakalan remaja. Hal ini sejalan dengan Shohib (2016:35) yang menyatakan dibutuhkan sebuah strategi pengelolaan bimbingan konseling yang baru untuk membantu siswa dalam memecahkan permasalahan pribadinya. Salah satu strategi yang dapat digunakan adalah dengan membentuk kelompok konselor sebaya.

Secara teoritis, pembentukan dan penerapan konselor sebaya ini merupakan salah satu pemanfaatan dari fungsi teman sebaya. Seperti dikatakan sebelumnya fungsi teman sebaya dapat dibedakan menjadi tiga yaitu (1) Sebagai sumber informasi mengenai dunia di luar keluarga. (2) Sumber kognitif, untuk pemecahan masalah dan perolehan pengetahuan. (3) Sumber emosional, untuk mengungkapkan ekspresi dan identitas diri. Salah satu fungsi terpenting dalam sebaya adalah memberikan sumber informasi dan perbandingan tentang dunia luar keluarga. Anak -anak menerima umpan balik tentang kemampuan mereka dari grup sebaya mereka (Santrock, 2007:205). Melalui sebaya remaja belajar menjadi pasangan-pasangan yang terampil dan sensitif dalam hubungan dekat dengan membentuk persahabatan yang erat dengan sebaya terpilih (Sullivian dalam Santrock, 2007:205).

Sedangkan pembentukan dan penerapan konselor sebaya termasuk kedalam tiganya. Hal tersebut bedasarkan jenis-jenis layanan yang dapat diberikan oleh konselor sebaya. Dalam layanan bimbingan dan konseling terhadap berbagai fungsi antara lain (a) Pemahaman, yaitu fungsi untuk membantu peserta didik memahami diri dan lingkungannya, (b) Pencegahan, yaitu fungsi untuk membantu peserta didik mampu mencegah atau menghindarkan diri dari berbagai permasalahan yang dapat menghambat perkembangan dirinya, (c) Pengentasan, yaitu fungsi untuk membantu peserta didik mengatasi masalah yang dialaminya, (d) Pemeliharaan dan pengembangan, yaitu fungsi untuk membantu peserta didik memelihara dan menumbuh-kembangkan berbagai potensi dan kondisi positif yang dimilikinya (Shohib, 2016:35). Bahkan, pelayanan tersebut tidak terbatas pada hal tersebut tetapi juga pada hal-hal yang terkait dengan persahabatan, kenakalan, serta hubungan percintaan teman sebaya.

Instansi tersebut nampaknya sangat memahami bagaimana dinamika anak dan remaja di wilayahnya. Mereka memeahami kondisi lingkungan yang dapat memberi dampak buruk pada perkembangan anak dan remaja. Mereka juga memahami bagaiman sifat remaja yang lebih memilih curhat kepada teman sebaya dari pada orang tua. Serta bagaimana dampak positif yang bisa ditimbulkan melalui penerapan teman sebaya Hal ini dapat dipahami karena periode remaja merupakan periode yang sangat dekat dengan peer group, membutuhkan pengakuan dari kelompok atau teman sebaya dan membutuhkan identitas baru yang bisa meningkatkan harga dirinya (Hurlock, 2002).

Selama tiga tahun kota Surabaya telah membuktikan keefektifan program konselor remaja. Dan saat ini, menurut Ikhsan (Kepala Dinas Pendidikan), program tersebut berkembang menjadi ekstra kulikuler siswa. Hal tersebut 
menunjukkan bahwa program yang diterapkan pada awalnya sebagai suatu instruksi saat ini telah berkembang menjadi program wajib yang kemudian masuk kedalam ekstrakurikuler. Sehingga setiap kelas dalam sekolah wajib memiliki dua perwakilan untuk dilatih menjadi konselor sebaya melalui pembinaan dalam ekstrakurikuler. Nampaknya perkembangan tersebut mendukung hasil penelitian yang dilakukan oleh Maryatun (2011:739) tentang proses penerapan konselor sebaya melalui PIK R/M, yang menyatakan bahwa dari 20 kelompok PIK R/M 16 kelompok telah memberdayakan konselor sebaya dengan baik dampaknya terjadi perkembangan dan perubahan perilaku siswa yang positif dari sebelumnya memiliki kecenderungan berperilaku negatif.

Praktik tentang kota Surabaya yang menerapkan program konselor sebaya menjadi bagian informasi rujukan tentang efektivitas penerapan konselor sebaya. Sehingga konselor sebaya memiliki peranan yang vital dalam membantu sekolah maupun masyarakat untuk membentuk dan membina remaja menjadi individu-individu berkarakter lebih baik terhindar dari bahaya - bahaya yang saat ini identik dengan perilaku remaja dengan teman sebayanya serta mendorong anak atau remaja untuk berprestasi.

\section{KESIMPULAN}

Teman sebaya memberikan fungsi yang dominan dalam perkembangan perilaku dan kepribadian remaja. Melalui fungsi-fungsi grup sebaya remaja mengembangkan dirinya. Terutama dalam upaya untuk menjalin hubungan pertemanan bahkan percintaan yang mulai tumbuh pada masa remaja. Dari sinilah pemberdayaan teman sebaya sebagai konseling sebaya perlu digalakkan. Konselor remaja melalui beberapa penerapan dan penelitian menunjukkan efektivitasnya. Terutama dalam kaitannya untuk membimbing dan mengarahkan sebanyanya untuk membentengi diri dari pengaruh negatif lingkungan.

\section{SARAN}

Dalam pemberdayaan teman sebaya untuk menjadi konselor sebya hendaknya pihak guru tetap mendampingi proses pemberdayaan tersebut. Hal ini dikarenakan teman sebaya juga merupakan anak-anak sesusia yang juga belum sepenuhnya memiliki pemikiran dan pengalaman yang cukup dalam memecahkan masalah yang komplek. Sehingga guru hendaknya secara berkala memberikan pelatihan, pembinaan dan pendampingan guna meningkatkan kompetensi anak yang dijadikan sebagai konselor sebaya.

\section{DAFTAR RUJUKAN}

Ardi, Zadrian., Ibrahim, Yulidar., \& Said, Azrul. 2012. Capaian Tugas Perkembangan Sosial Siswa dengan Kelompok Teman Sebaya dan Implikasinya terhadap Program Pelayanan Bimbingan dan Konseling. KONSELOR: Jurnal Ilmiah Konseling, (Online), 1 (1): 1-5, (http://ejournal.unp.ac.id/index.php/konselor/article/view/522/583), diakses tanggal 21 November 2016. 
Badan Kependudukan dan Keluarga Berencana Nasional (BKKBN). 2012. Pedoman Pengelolaan Pusat Informasi dan Konseling Remaja dan Mahasiswa $(P I K R / M)$. Jakarta: Direktorat Bina Ketahanan Remaja BKKBN.

Desmita. 2015. Psikologi Perkembangan. Bandung: PT. Remaja Rosdakarya.

Hakim, Abdul. 2016. Dinas Pendidikan Surabaya Terapkan Program Konselor Sebaya. (Online), (http://www.antarajatim.com/berita/ 177664/dinaspendidikan-surabaya-terapkan-program-konselorsebaya?utm_source $=$ fly\&utm_medium=related\&utm_campaign=news), diakses 28 Oktober 2016.

Hidayati, Novi Wahyu. 2016. Hubungan Harga Diri dan Konformitas Teman Sebaya dengan Kenalan Remaja. Jurnal Penelitian Pendidikan Indonesia (JPPI), 1 (2): 31-36.

Hurlock, E.B. 2002. Psikologi Perkembangan. terj. Istiwidiyanti dan Soedjarwo. Jakarta: Erlangga.

Maryatun, Wahyuni. 2011. Metode Clinic-Based dan Community Empowerment pada Pemberdayaan Pendidik dan Konselor Sebaya dalam Program Kesehatan Reproduksi Remaja di Kabupaten Sukoharjo. Gaster: Jurnal Ilmu Kesehatan, (Online), 8 (2): 731-740, (http://www.jurnal.stikesaisyiyah.ac.id/index.php/gaster/article/view/24), diakses tanggal 28 Oktober 2016.

Pratiwi, NL., \& Basuki, Hari. 2011. Hubungan Karakteristik Remaja Terkait Risiko Penularan HIV-AIDS dan Perilaku Seks Tidak Aman di Indonesia. Buletin Penelitian Sistem Kesehatan, (Online), 14 (4): 346357,(http://ejournal.litbang.depkes.go.id/index.php/hsr/article/view/1372) diakses tanggal 21 November 2016.

Santrock, John W. 2007. Perkembangan Anak. terj. Mila Rachmawati \& Anna Kuswanti. Jakarta: Erlangga.

Shohib, Muhammad, dkk. 2016. Pendampingan Kelompok Konselor Sebaya di Kota Batu. Jurnal Dedikasi, (Online), 13 (1): 34-38, (http://ejournal. umm.ac.id/index.php/dedikasi/article/view/3135), diakses tanggal 28 Oktober 2016.

Suwarjo. 2008. Konseling Teman Sebaya (Peer Counseling) untuk Mengembangkan Resiliensi Remaja. Makalah disajikan dalam Seminar Pengembangan Ilmu Pendidikan Fakultas Ilmu Pendidikan Universitas Negeri Yogyakarta, Yogyakarya, 29 Februari 2008.

Usman, Irvan. 2013. Kepribadian, Komunikasi, Kelompok Teman Sebaya, Iklim Sekolah dan Perilaku Bullying. Humanitas, 10 (1): 49-60.

Wahid, LA. 2013. Konseling Sebaya Bagi Remaja (Tinjauan Teoritis dalam Mengatasi Problematika Remaja Persepektif Bimbingan dan Konseling). Al Tazkiah, (Online), 2 (1): 1-16, (http://ejurnal.iainmataram.ac.id /index.php/tazkiyah/article/download/744/988) diakses tanggal 21 November 2016.

Yusuf, Syamsu. 2016. Psikologi Perkembangan Anak \& Remaja. Bandung: PT. Remaja Rosdakarya. 